\title{
A Policy Lens of South Carolina Coastal Stormwater Management
}

\author{
Lori A. Dickes ${ }^{1}$, Jeffery Allen², Monika Jalowiecka ${ }^{3}$, Katie Buckley ${ }^{4}$
}

\begin{abstract}
AUTHORS: ${ }^{1}$ Director, Master Public Administration Program, Clemson University, Strom Thurmond Institute, Clemson, SC, 29634, USA. ${ }^{2}$ Director, South Carolina Water Resources Center, Clemson University, Clemson, SC, 29634, USA. Environment and Sustainability Program, University of South Carolina, , Columbia, SC, 29201, USA. ${ }^{4}$ Director, Clemson University Center for Watershed Excellence, Clemson, SC, 29634, USA.
\end{abstract}

\begin{abstract}
Similar to many environmental issues today, stormwater management lies within a network of regulatory and policy oversight. As South Carolina coastal communities continue to experience economic and population growth, understanding the broader policy context of stormwater pond management is important. This study was aimed at compiling the state-of-theknowledge of stormwater pond management policy for the eight coastal counties of South Carolina. In order to enhance researchers and policymakers understanding of the stormwater policy and regulatory environment, this research utilizes a mixed methods approach. A mixed methods approach allows researchers to explore different components of a particular research question by deploying more than one methodological tool.

This research employed three primary qualitative techniques: a policy instrument scan, a regional online survey and a local policy and economic focus group. Results indicate that while potentially strong policy exists at all levels (federal, state and local), there are identified gaps and stakeholder concerns around policy implementation and proper stormwater pond management at the local level. Additionally, with many stormwater ponds managed by Homeowners' Associations (HOAs) there appears to be wide variation in their management and maintenance. Some of the recommendations identified in these results include: encouraging more Low Impact Development (LID) practices both for new development and re-development, improved communication on and best practices in pond maintenance, research and development of alternative pond management methods, more effective communication from South Carolina Department of Health and Environmental Control (DHEC) related to design criteria, effective maintenance and training opportunities for engineers preparing stormwater plans, and improved education for developers and HOAs. This document provides a framework to help lay the foundation for future stormwater pond policy studies that can assist policy
\end{abstract}

makers, managers, stakeholders and other decision makers to more fully understand issues impacting water resource management in South Carolina.

\section{INTRODUCTION}

South Carolina continues to be an attractive state for new businesses, business expansion, retirees, out of state second homeowners and young professionals looking for a good quality of life at a relatively low cost. The 2030 population projections for South Carolina counties reveal growth rates ranging from as low as $5 \%$ to as high as $50 \%$. South Carolina coastal counties are projected to have similar rates of population growth ranging from approximately $2 \%$ to almost $30 \%$ from $2015-2030$.

The resulting urban and suburban growth across the region increases the perceived need and demand for impervious surfaces to support associated development. While pervious paving methods are available, and their use is on the rise, full acceptance and implementation have been slow across the state. For the most part, South Carolina roads, sidewalks and parking lots still use impervious materials, with no associated penetration of water so sediment, nutrients and other pollutants run off into receiving waterways (Davis, et al., 2010). The larger the impervious surface, the less likely that stormwater will be absorbed naturally into the ground.

The United States Environmental Protection Agency (US EPA) reveals that stormwater runoff increases in direct correlation to the amount of impervious surface in a watershed region (US EPA, 2011, White and Greer, 2006). There is also evidence that impervious surfaces create channels for stormwater runoff and other pollutants to move directly towards bodies of water (Davis, et al., 2010). The US EPA documents a range of problems resulting from this runoff, including flooding, erosion, pollution, habitat loss, stream flow changes, and changes in turbidity. As well, stormwater absorbed naturally into the environment is critical to the natural filtering and replenishing of our water 
supply. To minimize the impact of impervious surface cover and stormwater runoff, stormwater ponds are used as a best management practice (BMP) as described by the US EPA. Specifically, the US EPA defines a stormwater BMP as a "technique, measure, or structural control that is used for a given set of conditions to manage the quantity and improve the quality of stormwater runoff in the most cost-effective manner (SafeDrain, 2010)." There are three primary purposes of stormwater ponds: to reduce flooding, to reduce water pollution and to enhance the landscape (Powell, 2009). There are two primary types of ponds used for stormwater management: wet detention ponds and retention ponds. Wet detention ponds are those with a permanent pool of water, which gradually discharges stormwater into adjoining bodies of water (Vandiver and Hernandez, 2009, SCDHEC, 2007). Stormwater retention ponds also have a permanent pool of water but water is discharged through infiltration, groundwater transport and/or evapotranspiration (Vandiver and Hernandez, 2009, SCDHEC, 2007).

Research from 2007 documents nearly 10,000 stormwater ponds in the coastal region of South Carolina (SCDHEC, 2007). Research recently completed, but not released, through South Carolina Sea Grant documents a substantial increase in the number of coastal stormwater ponds over the past nine years. Residential subdivisions contain the majority of ponds. Moreover, as most subdivisions are governed by homeowners' associations (HOAs), these groups are largely responsible for the management, maintenance and repair of stormwater ponds. A 2007 study by the South Carolina Department of Health and Environmental Control-Office of Ocean and Coastal Resource Management (SCDHEC-OCRM) Stormwater Maintenance Program reported almost 15\% non-compliance of permitted ponds from inspections of approximately 511 residential development sites (SCDHEC, 2007); in 2007 equating to over 1500 ponds. In the coastal region of South Carolina, non-compliance can occur for several different reasons; for example, inappropriate vegetation, poor maintenance or control of vegetation, clogged intake or outtake pipes, significant sediment buildup preventing effective water flow and others that may reduce the effectiveness of the stormwater pond.

As these coastal communities continue to experience economic and population growth, understanding the broader policy context of stormwater pond management is a critical component to sustainable growth and development in the future. In order to accomplish such growth and development, this research will begin to describe the policy context for stormwater policy in the Coastal region of South Carolina. This paper will begin with a description of the research approach and underlying methodology. This will be followed by a review of the layered policy and regulatory environment surrounding stormwater pond regulation and maintenance. As with many environmental polices, the implementation occurs at the local level. As such, the next section of the paper focuses on the results of a Coastal region focus group concentrating on the policy and economic environment of stormwater pond regulation and maintenance. Finally, conclusions and suggestions for future research and policy considerations will be examined.

\section{PROJECT DESCRIPTION AND METHODOLOGY}

The impetus for this research is the growing need to more effectively plan and manage stormwater policy across the Southeastern United States coastal regions. Many of these regions have been and continue to experience economic and population growth, amidst ongoing concerns of climate pressures and variation in weather related stresses. With these pressures in mind, this research seeks to explore two primary research questions. First, is there a perceived local need to change local stormwater policy and regulation. Second, if there is a perceived need, where in the policy/ regulatory hierarchy is this most likely to occur?

Using South Carolina coastal communities as a sample to understand stormwater policy and regulation, this research utilizes a mixed methods approach. A mixed methods approach allows researchers to explore different components of a particular research question by deploying more than one methodological tool. This research employs three primary qualitative techniques: a policy instrument scan, a regional online survey and a local policy and economic focus group.

The United Nations Environmental Programme describes a policy instrument scan as one designed to go beyond understanding the broader regulatory and policy environment by attempting to describe the broadest mix and range of policy instruments that influence the policy environment of specific issues (UNEP, 2016). An accurate policy scan addresses policy tools that are having both a positive and a negative impact on the policy landscape, with particular focus on the chain of policy instruments, the hierarchy of regulatory and policy tools, along with external and/or internal political or private pressures. This is a critical exercise with any complicated policy and regulatory environment. For environmental issues, in particular, this analysis can be useful for policymakers and researchers.

After understanding the broad policy and regulatory environment, this research employed both an online survey and a focus group methodology to document the stormwater policy environment at a local level. An online survey instrument was developed in conjunction with College of Charleston researchers focusing on the economics of stormwater management. The survey instrument was sent to email lists of local and municipal stormwater managers and other direct stormwater stakeholders.

Focus groups allow researchers a more in depth look at specific issues by meeting directly with impacted stakeholders and providing an environment that allows for more in depth questions and conversation. For this research, we held one focus group in North Charleston, South Carolina. We invited a range of stakeholders, including municipal stormwater professionals, related local utilities, private professionals impacted by stormwater regulation and management (i.e. 
builders, homeowners' associations). The results of the survey and focus group are described later in the paper. Both tools enhance our understanding of the current policy and regulatory environment of stormwater issues. Before we explore these results, the layers of stormwater policy and regulation are described in more detail in the next section.

\section{Federal Law}

Similar to many environmental issues today, stormwater management lies within a network of federal, state and local policy and regulation. United States environmental policy and regulation, including stormwater, mimics the federalist system in general; with federal and state policies that set standards, have regulatory power and may provide some funding streams, while local municipalities are often left to interpret, implement and/or innovate within this larger policy context. In these environments, it is useful to identify the dominant, overlapping or even conflicting policies or regulations that impact a particular issue.

What follows is a brief overview of the federal, state and local policy and regulations related to stormwater pond management and regulation. As with many environmental policy areas, there are several key or landmark policies. For stormwater policy at the Federal level, the 1972 Clean Water Act (CWA) amendments and its provisions for the National Pollutant Discharge Elimination System (NPDES) are key pieces of legislation. The research will start at the federal level with these key policies and work down to the local or municipal level. At the conclusion of this section, a review of the identified policy hierarchy and potential policy overlap will be explored.

\section{Clean Water Act (CWA)}

The basis of the Clean Water Act was the 1948 Federal Water Pollution Control Act. This act granted states the primary responsibility for water pollution. Substantial amendments in 1972, saw the evolution of the Clean Water Act towards the regulatory policy we are familiar with today. The Clean Water Act is a complex regulatory scheme governing water pollution control, including pollution caused by stormwater runoff. At the heart of the CWA is the establishment of water quality standards applicable to designated uses of waterbodies. Under Section 303(d) of the CWA, every two years, states are required to use available water quality data to identify waters that do not meet established water quality standards or are likely not to meet them in the next reporting cycle. These impaired waters are subject to further planning and management designed to bring the waterbody into compliance with water quality standards. For stormwater discharged into water bodies through storm drains, the CWA requires cities and counties meeting a certain population threshold to obtain a National Pollutant Discharge Elimination (NPDES) permit to monitor, reduce and control pollutants contained in stormwater runoff within their jurisdictions. In addition, certain industrial and construction activities must obtain a permit to manage stormwater runoff (US EPA, 2015).
Several key sections of the CWA that impact stormwater policy and regulation are worth further explanation. Specifically, Section 208 covers regional water quality management plans and Section 303(d) pertains to waters that remain polluted after attempted remediation efforts. Section 208 in South Carolina only addresses wastewater facilities and generally, refers specifically to nonpoint sources of pollution. Section 303(d) also includes the Total Maximum Daily Load program, which aims to apportion waste load allocations to reduce the overall pollutant impact on impaired waterbodies. While TMDLs apply to a range of sources and outputs, stormwater discharges are an increasingly prevalent source for TMDLs (USNRC, 2008).

Further, Section 401 of CWA requires SCDHEC's certification for activities requiring a federal permit and which may discharge to State waters; for example, dredge or fill permits or hydropower licensing permits (Ellis, et al., 2014). Increasingly smaller municipalities and smaller construction activities are required to meet NPDES stormwater regulations, thereby requiring additional policy guidelines and specification of TMDL allocations from the EPA and corresponding state agencies (US EPA, 2015).

CWA Sections 301 and 402 pertain to the controlled release of toxins, with larger municipalities focusing on treatment using advanced technology, and stormwater regulation through management and permit programs within urban areas (USNRC, 2008). Section 402 also requires an NPDES program (see below) (Geer, 2015). As a 2015 extension to the CWA, the Clean Water Rule states if particularly large stormwater discharge flows into the nation's waters downstream, stormwater can be considered jurisdictional waters and must follow the practices set forth under the CWA (US EPA, 2015).

National Pollutant Discharge Elimination System (NPDES)

The NPDES program is overseen by the US EPA and as mentioned above is implemented in Section 402 of the CWA amendments. The NPDES is implemented in South Carolina by SCDHEC under the state Pollution Control Act (SCDHEC, 2007, Ellis, et al., 2014, Geer, 2015). Under the NPDES, SCDHEC issues permits with effluent limits on pollutants along with a best management practice and recommended stormwater treatment (Ellis, et al., 2014). These permits are divided into regulated municipal separate storm sewer systems (MS4s) (SCDHEC, 2014-B), Construction General Permits (CGPs) (SCDHEC, 2007), and multi-sector industrial stormwater general permits (MSGPs) (USNRC, 2008). For stormwater MS4 and General permits for industrial and construction activities there are no effluent limitations. These permit types apply uniquely to Phase I and Phase II in the NPDES permitting process.

In Phase I, the following conditions require permits: MS4s serving municipalities of 100,000 or more people, CGPs for all construction sites that disturb five or more acres, and MSGPs for 11 specified industrial activities which disturb five or more acres of land. Phase II parameters are: MS4s serving municipalities of 10,000 to 100,000 people, 
CGPs for construction sites that disturb between one and five acres, and MSGPs for activities disturbing one to five acres (Ellis, et al., 2014, SCDHEC, 2014-B). Phase II also requires a stormwater pollution prevention plan and a notice of intent (SCDHEC, 2007). MS4 status and its implementation at the local level is a growing issue across Coastal South Carolina.

Currently, several counties and municipalities are regulated under three different MS4 permits. These permits include the Charleston Area MS4, the Myrtle Beach Area MS4 and the Beaufort County SMS4. The two coastal counties not included in the MS4 program are Jasper and Colleton.

The CWA and related NPDES are the primary Federal policies and regulations impacting stormwater regulation at the state and local level. However, there are four additional federal policies that can potentially impact stormwater policy and management. These are briefly described in the next section.

The next three Acts discussion, the Endangered Species Act (ESA), the National Environmental Policy Act (NEPA) and the National Historic Preservation Act (NHPA) are all federal policies that may have little, if any, impact on stormwater regulation unless there is a specified federal action. For example, in the case of NEPA, if the Environmental Protection Agency issues a general permit it is technically a federal action, however, as permit issuance has largely been delegated to the states, courts have largely argued that NPDES permits are not considered a federal action. As states are delegated additional regulatory powers, the significance of these federal statutes is called into question (Gaba, 2007). Even with this, a brief mention of these Acts and their scope is important to paint a complete picture of this policy and regulatory environment.

\section{Endangered Species Act (ESA)}

Under the ESA, stormwater discharge has to be reduced to a safe level if seen as a continuous threat to a given species listed as threatened, endangered, or recovered (USNRC, 2008). The ESA also applies where the destruction of alteration of habitat negatively impacts a species. Previously this was a state responsibility, however the federal government now handles the ESA component in NPDES permitting (Ellis, et al., 2014, SCDHEC, 2010). As of 2015, 18 endangered, threated, or recovering species have been listed in the eight SC coastal counties by the U.S. Fish and Wildlife Service (USFWS, 2015).

\section{National Environmental Policy Act (NEPA)}

The National Environmental Policy Act states that environmental impact reviews must be conducted for a new or extended industrial discharge prior to the issuance of an industry NPDES permit. A New Source Determination must be filed by the discharger, which describes a new or expanded industrial project, to determine if an environmental assessment needs to be filed (Ellis, et al., 2014). However, as noted earlier, obligations under NEPA are only triggered in cases of federal actions and state issued general permits are not typically considered a federal action. Moreover, permit authority has largely been delegated to the states (Gaba, 2007).
National Historic Preservation Act (NHPA)

Depending on the location of the stormwater runoff, national historic sites may be affected within the eight coastal counties (USNPS, 2015). The eight Coastal counties are some of the earliest settled sites in the state and are replete with a range of historic sites. When these sites are identified, this may alter present/future stormwater management designs. Similar to the ESA, administrative rights for the NHPA requirement has been moved from SCDHEC to the federal government through the NPDES permitting process (Ellis, et al., 2014, SCDHEC, 2010).

\section{Coastal Zone Management Act (CZMA)}

Finally, the CZMA is a federal policy which arguably coincides with South Carolina's Coastal Management Program (SC CMP). Any activity requiring NPDES permits must certify that the proposed activity complies with CZMA and the SC CMP for the activity affecting water or land use within the coastal region (Ellis, et al., 2014). This certification, known as the Coastal Zone Consistency Certification (CZC), is required before a NPDES and any other state permit can be issued.

\section{South Carolina Law}

Federal policy and regulation can impact state and local regulation and implementation in a range of ways. Federal policy may authorize states to enact policy or regulate, it may require certain types of intervention and regulatory oversight from states, or it may mandate specific planning, technology or other best practices at the state or local level among others. This section reviews the state laws and regulations that impact stormwater policy in South Carolina, all of which have clear relationships to federal policy and/or local/municipal policy (SC Legislature, 2014).

\section{Pollution Control Act (PCA)}

This act states that it is unlawful to directly or indirectly discharge into the environment unless one has been authorized to do so in compliance through a permit issued by DHEC (Ellis, et al., 2014), the governing SC agency assigned to protect the environment and implement this act (SCDHEC, 2007). This is the state level policy that implements the federal NPDES permitting regulations.

The PCA is composed of water pollution control permits, which are divided into general and individual permits. General permits are allocated to industrial activity, construction activity, and Small MS4s. Individual permits are allocated to Large and Medium MS4s, along with permits issued to various industrial sites as well as a few construction activities (Ellis, et al., 2014).

\section{South Carolina Coastal Management Program (SC CMP)}

The SC CMP was established by the federal Coastal Zone Management Program and is divided into the three primary acts detailed below (SCDHEC, 2011, SCDHEC, 2014-A). 


\section{A Policy Lens of South Carolina Coastal Stormwater Management}

1. Coastal Zone Consistency Permits (CZC Permits: These permits ensure activities involving land and water uses within coastal counties are consistent with the federal Coastal Zone Management Plan and SC Coastal Zone Management Act through a Consistency Determination (Ellis, et. al., 2014).

2. Coastal Tidelands and Wetlands Act (CTWA): This act was created to protect and ensure long-term sustainability of the vulnerable areas of the SC coast. This Act encourages and allows state and local governments to protect coastal areas based on their ecological, economic, cultural, and social value (SCDHEC, 2014-A, SCDHEC, 2011).

3. Stormwater Management and Sediment Reduction Act (SMSRA): This Act is broken into three components, the first being the Erosion and Sediment Reduction and Stormwater Management Regulations, which sets regulations for state land to avoid damage to property, land, and water caused by erosion, sediment, and stormwater. Part two contains the Standards for the SMSRA, which suggests a statewide stormwater management and sediment reduction program as a preventative measure against current and future water quality and quantity problems. Part three is the Amendment to the Standards for SMSRA, tying highway construction, infringement permits or easement, and/or right-of-way work related to the SC Department of Transportation (SCDHEC, 2007).

This program further established requirements for any development project located next to a receiving water body, shellfish beds, areas producing significant runoff, as well as other activities which may provide substantial influence to water bodies. For example, one important regulatory consideration is the size of the area disturbed by the proposed project (Ellis, et al., 2014, Geer, 2015, and SCDHEC, 2007).

Erosion and Sediment Reduction and Stormwater Management Regarding state owned land, this policy details requirements for erosion and sediment control and sets stormwater management methods to prevent damage to land, property, and water. R.72-106(E) sets the standards and specifications that must be met to control erosion and stormwater for projects on state property. Stormwater ponds are one of the tools identified as a method to manage stormwater, erosion and sediment control on state lands (Ellis, et al., 2014).

In addition to state policy and regulation, many county and local governments have best management practices related to stormwater ponds. Whether in a comprehensive plan or through community design ordinances, stormwater management plans require the design of stormwater management infrastructure that meets specifications of state or local design manuals.

As this discussion has illustrated, two key state policies have an important impact on stormwater policy and regulation in the state. The PCA and SC CMP both have relationships to federal policy and depending on the circumstances may require action at the local level. Given this, the next section briefly describes local policy and regulation of stormwater issues.

\section{Local Government Management}

Given the size and variation in how counties implement stormwater policy and regulation, researchers chose to do an online policy scan of the eight South Carolina coastal counties. This section describes the scope and type of online tools and information related to stormwater policy, planning and regulation across these communities. The overall purpose of the assessments below is solely to gauge differences and similarities among how counties and municipalities approach stormwater management information and access to it.

\section{Counties}

The legally-defined South Carolina coastal counties considered in this research are Beaufort, Berkeley, Charleston, Colleton, Dorchester, Georgetown, Horry, and Jasper. The methodology for a policy and regulatory scan varies; for this research, we chose an approach that considered a broad range of public areas where stormwater may be considered. A detailed review of available stormwater related documents on each county's web page was conducted, placing emphasis on criteria such as having a stormwater website, a stormwater management plan, and an ordinance document available online. While zoning did not regularly appear on each county's website, we included it as a criterion because classifying land use and current/future building codes may serve as a proxy for stormwater management and may in fact be an important tool in stormwater management (USNRC, 2008). Further, it is worth noting that the SC Comprehensive Planning Act does not require local governments to incorporate stormwater management but does not prevent this either (SC Code Ann. 6-29-510).

Of the eight counties, Colleton was the only county with all of the assessed criteria missing, yet there was not a single county which readily met all seven specific criteria or the eighth more general "other" criteria identified in Table 1. The most significant gaps in the criteria appear to be with counties comprehensive plans, where approximately $75 \%$ of the counties did not incorporate stormwater into their comprehensive plans or zoning (Beaufort County, 2015, Berkeley County, 2015, Charleston County 2015, Colleton County, 2015, Dorchester County, 2015, Georgetown County, 2015, Horry County, 2014, Jasper County, 2015).

Several of the comprehensive plans briefly mention stormwater concerns or challenges in the respective county, but only vaguely mention the need for future regulation and monitoring. Thus, even when stormwater is mentioned, it is with little depth or clarity about policy, regulation or management. The exceptions to this were Horry and Jasper Counties, with Jasper's plan providing exceptional detail on how to tackle stormwater issues in the county (Horry County, 2014, Jasper County, 2015). 
Jasper County was also the only county which incorporated a section concerning zoning on the stormwater page (Jasper County, 2015). While none of the other counties had a site dedicated to zoning, several of them referenced zoning in other stormwater documents (Beaufort County, 2015, Berkeley County, 2015, Charleston County 2015, Dorchester County, 2015). For example, in Berkeley County's Stormwater Design Standards Manual, zoning was mentioned under the Zoning and Land Development Regulations as well as the Building \& Codes and Floodplain Ordinances (Berkeley County, 2015). Just because county websites do not directly reference zoning does not mean the county avoided the subject completely within the stormwater page.

The overall purpose of developing the matrix that is depicted in Table 1 was to analyze each of the counties based on the presence or absence of previously determined measures. This table cannot accurately categorize one county as more involved in stormwater management than another based on the number of present criterion, but rather provides a snapshot of potential differences across counties in stormwater regulation and management. It would be inaccurate to label one county as superior or inferior in stormwater management based on the number of checked criteria. Even when present, these documents are not uniform across counties and the lack of one document may be compensated with the depth of material presented in another document. Previously written stormwater reports covering the same eight coastal counties fail to mention analysis of the county's online resources. As such it was important that this analysis did a thorough website scan of county level stormwater policies.

Table 1. County website stormwater information

\begin{tabular}{|c|c|c|c|c|c|c|c|c|}
\hline & 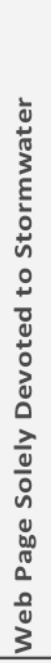 & 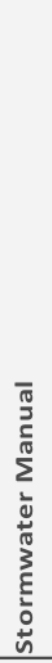 & 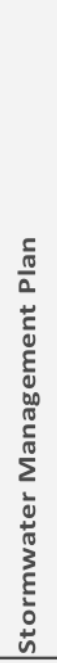 & 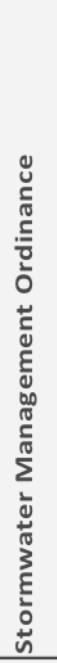 & 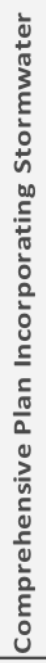 & 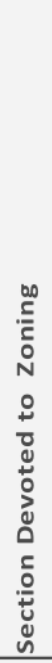 & 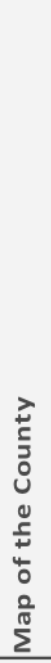 & 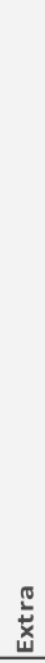 \\
\hline Beaufort & $\checkmark$ & $\checkmark$ & $\checkmark$ & 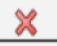 & 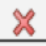 & 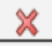 & $\checkmark$ & $\checkmark$ \\
\hline Berkeley & $\checkmark$ & $\checkmark$ & $x$ & $\checkmark$ & $\Sigma$ & $x$ & $\checkmark$ & $\checkmark$ \\
\hline Charleston & $\checkmark$ & $\checkmark$ & $\checkmark$ & $\checkmark$ & $x$ & $x$ & $x$ & $\checkmark$ \\
\hline Colleton & $x$ & $x$ & $x$ & $x$ & 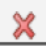 & $x$ & $x$ & $x$ \\
\hline Dorchester & $\checkmark$ & $\checkmark$ & 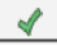 & $\checkmark$ & $x$ & $x$ & 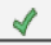 & $\checkmark$ \\
\hline Georgetown & $\checkmark$ & $\checkmark$ & $x$ & $\checkmark$ & $x$ & $x$ & 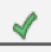 & $\checkmark$ \\
\hline Horry & $\checkmark$ & $\checkmark$ & $q$ & $\checkmark$ & $q$ & $x$ & $\checkmark$ & $\checkmark$ \\
\hline Jasper & $x$ & $\checkmark$ & $x$ & $\checkmark$ & $\checkmark$ & $\checkmark$ & $x$ & $\checkmark$ \\
\hline
\end{tabular}

Municipalities

The following five cities, Beaufort, Charleston, Georgetown, Mt. Pleasant, and Myrtle Beach, were chosen for additional website/policy review. Several of these cities are predicted to have both future population growth and increased tourism, both of which heavily depend on proper stormwater management for sustainable growth. A detailed review was conducted in a similar fashion as for the counties, but relevant criteria included city stormwater budgets, city stormwater contact information, and available educational tools for residents.

The only criteria that all counties had in place was stormwater contact information and stormwater service. There also appears to be distinct similarities between the documentation and style of Beaufort and Georgetown and Myrtle Beach and Mt. Pleasant, with the latter two municipalities having more detailed information available (City of Beaufort, 2015, City of Charleston, 2015, City of Myrtle Beach, 2010, Georgetown, SC, 2014, Town of Mt. Pleasant, 2015). Mt Pleasant is the city missing the fewest criteria, with only one identified gap for direct stormwater identification in the city budget. Similar to the counties, this scan provides some initial insight into the information that these communities provide on stormwater issues broadly but does not provide evidence of the strengths or weaknesses of specific policies or regulation.

After reviewing federal and state laws and local information resources related to stormwater policy and regulation, some conclusions can be drawn. The CWA's NPDES program authorizes and sets the regulatory environment for SCDHEC to implement stormwater policy and regulation. Much of the existing state policy and regulation mirrors the regulatory framework created at the federal level. This federal/state relationship is further reinforced as states are delegated authority to issue permits and other regulatory tools related to stormwater management.

It is also important to note the role of South Carolina's Councils of Governments (COGs) in stormwater management. The COGs assist counties and municipalities in various planning and management areas. Many of the COGs assist with comprehensive planning, which may include stormwater management. Most COGs do not have staff trained in this area and depend on other government agencies or consultants to assist with stormwater management implementation at the local level.

At the local level, municipalities appear to be trying to meet current regulatory expectations but information and planning at the local level appears to be quite varied across the eight county SC coastal region. To gain more depth and insight into local concerns and issues, the next section discusses a survey and focus group of stormwater professionals.

\section{SURVEY AND FOCUS GROUP RESULTS}

In order to have a better understanding of municipal stormwater policy and regulation, researchers implemented a survey and a focus group targeting stormwater managers 
and other related stakeholders. The survey was implemented in collaboration with the College of Charleston research team working on the economics of stormwater policy and management. The IRB process was managed by the College of Charleston research team. Working together, each team developed 10-15 questions covering a range of economic and policy issues. The survey was distributed using the online survey platform, Qualtrixx, to a wide range of stormwater managers and related professionals across the eight county coastal region. Reminders were sent to potential participants over a 4-6 week period in June-July, 2015. Survey and focus group respondents represent a range of professionals, including stormwater professionals from counties designated as an MS4 NPDES permittee.

Policy questions focused on a range of issues including organizational responsibility, alternative technologies, community planning, and effective regulation and management. Almost sixty percent of respondents believe that stormwater management should be a shared responsibility among agencies. Further, almost seventy percent of respondents address stormwater management in their community's comprehensive plan. Of those that answered yes to the comprehensive management plan question, over sixty percent of respondents agree or strongly agree that the comprehensive plan is the most effective place to address stormwater issues, while thirteen percent disagree.

Stormwater ordinances are a tool that communities can use to manage and enforce stormwater pond policy and best practices. The majority of respondents did not agree that stormwater ordinances are a barrier to economic development. Further, respondents were mixed in their agreement or disagreement with whether population growth demands flexibility with stormwater ordinance and policy. Figure 1 illustrates that forty-seven percent agree or strongly agree, while thirty-one percent disagree or strongly disagree. As these communities continue to grow, understanding how to manage growth with existing policy mechanisms is critical.

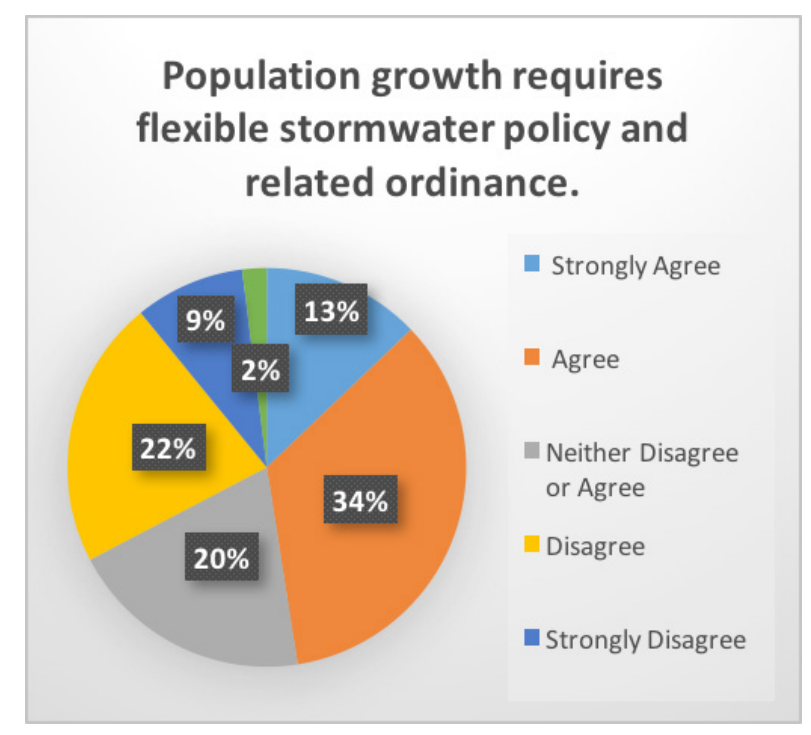

Figure 1. Population growth and stormwater policy.
A number of questions in the survey addressed which organization(s) (i.e. DHEC, counties, local governments) are best suited to manage and enforce stormwater policy. Table 2 illustrates that respondents are split twenty-four percent agree, twenty six percent disagree, and forty-three percent neither agree not disagree with the idea that stormwater ponds are the best tool for stormwater management. This question underscores some of the inherent policy challenges with stormwater management. Similarly, with regard to whether stormwater ponds, in compliance with state policies, are an adequate measure to manage stormwater has equally mixed responses.

Current state laws require DHEC to regulate and monitor stormwater ponds across the state, while local governments with stormwater NPDES permits regulate ponds within their jurisdictions. When asked whether stormwater ponds are monitored adequately by DHEC, almost sixty percent strongly disagreed or disagreed. When asked whether current county/state/federal policies allow for the necessary changes for future stormwater management, results reveal another set of mixed responses, with exactly thirty percent agreeing and thirty percent disagreeing.

Final survey questions allowed for open ended responses related to stormwater best practices, policy and management. With regard to policy and management, respondents were asked whether they believe there are any policy changes important for future stormwater management. Some of the comments focused on the following ideas.

- Require more Low Impact Development (LID) practices both for new development and redevelopment

- Improved maintenance, more progressive and restrictive design criteria

- Research/development of alternative management methods

- Strong prescriptive regulation

- Incorporate LID incentives into local and state development standards

- Need to have public/private partnerships

- DHEC to adapt new design criteria and provide regular training opportunities to engineers preparing stormwater plans and plan reviews

Table 2. Stormwater ponds are the best tool for stormwater management.

\begin{tabular}{|l|c|}
\hline Answer & $\begin{array}{c}\text { Percent of } \\
\text { Respondents }\end{array}$ \\
\hline Strongly Agree & $2 \%$ \\
\hline Agree & $24 \%$ \\
\hline Neither Agree nor Disagree & $43 \%$ \\
\hline Disagree & $26 \%$ \\
\hline Strongly Disagree & $4 \%$ \\
\hline
\end{tabular}


An additional question from the survey focused on the use of LID strategies for stormwater management. As defined by the EPA, LID is an alternative strategy to stormwater ponds that uses LID as an alternative strategy to stormwater ponds, utilizing natural landscape features like soils, vegetation, rainwater harvesting and other techniques that imitate nature's processes. Practices mentioned by the EPA as low impact are "bioretention facilities, rain gardens, vegetated rooftops, rain barrels and permeable pavements (https://www.epa.gov/nps/urban-runoff-low-impactdevelopment)." The ultimate goal of LID practices is to minimize the impact of the built environment and facilitate a more natural movement of water. Almost sixty percent of respondents strongly agreed or agreed that LID tools can be more a favorable management tool than stormwater ponds.

Overall, the survey yielded additional insights about stormwater pond policy across South Carolina's coastal zone. One of the key highlights is that stormwater pond professionals have mixed responses as to whether stormwater ponds are the most effective way to manage stormwater. This survey did not include property developers and as such may provide a different perspective if these professional were asked this question. Respondents are similarly mixed as to whether DHEC is able to provide an effective and flexible regulatory environment for stormwater pond management. The majority of respondents believe that stormwater pond management should be a shared responsibility across agencies and organizations. While open-ended responses varied, additional education, more robust public/private partnerships and additional use of LID practices were mentioned by more than one respondent. Overall, the survey highlights clear challenges in assigning responsibility for stormwater policy and management. The results underscore the importance of examining the current policy network and considering more effective policy organization for the future.

\section{Charleston Focus Group}

Focus group methodology allows researchers to explore critical issues in more depth with open ended discussion and response that cannot be achieve with a survey instrument. To provide a more in depth understanding of current stormwater issues and concerns, a focus group was held in North Charleston, South Carolina on July $22^{\text {nd, }}$ 2015. Facilitators included the researchers from Clemson University and the College of Charleston, the same research teams who also conducted the survey discussed previously.

Facilitators gathered a diverse group of eight community members composed of a commercial realestate agent, a Public Services Department representative, a Board Accountant for a Stormwater Manager, Stormwater Program Managers, an Assistant County Engineer, and a South Carolina Sea Grant Consortium representative. These individuals were chosen based on their diverse knowledge of stormwater issues and management. The focus group team developed ten key questions regarding stormwater policy and management. Each of the eight respondents were given an opportunity to answer each question in detail.

For the purposes of this research, we have highlighted focus group questions emphasizing stormwater policy and management more directly. Key questions identified are:

1. How would you characterize current state regulations, through DHEC, in managing and providing oversight of county stormwater ponds? Is it effective?

2. Who do you think should be responsible for stormwater management and why?

3. Is your community's Comprehensive Management Plan an effective tool for current and future stormwater management? Would another tool be more effective?

4. What future stormwater management policy changes would benefit coastal South Carolina counties?

5. What is one stormwater management strategy your county does which exemplifies effective and efficient stormwater management?

6. Do you foresee your county utilizing more LID solutions for future stormwater management control?

To ensure responses from individuals were properly noted, the entire conversation was recorded with the consent of all individuals in the focus group. The recording was then transcribed to ensure accurate documentation of the event discussions.

A number of common themes emerged. First and foremost, everyone in the group agreed that public education for stormwater management is a critical best management practice. Education was further broken down into several layers, including the individual level and the HOA level. There was much discussion on how to ensure HOAs understand the maintenance requirements of ponds, the costs of maintenance, how ponds operate, as well as when to contact the county stormwater manager with a substantial stormwater pond issue. The importance of knowing the most effective methods of educating homeowners, the public, HOAs, and others about stormwater ponds and best management of them was identified as critical.

There were multiple comments and concerns associated with the issue of HOAs and stormwater management. A major concern is that HOAs lack knowledge of what their delegated pond responsibilities are to begin with. There is also a lack of long-term planning on behalf of the HOA boards, such as when the board does not set aside finances from the yearly budget for pond maintenance. Additionally, when the pond is in desperate need of maintenance five, ten, twenty years after the pond was initially built, the board often does not have the funds to do this maintenance and receives opposition from the community when maintenance 
fees escalate. Additionally, HOAs have regular leadership changes and are often volunteer organizations with limited knowledge. All in all, the situation with HOAs and stormwater is a complex organizational and policy problem, which currently does not appear to be operating effectively for appropriate stormwater management.

Another common theme discussed by nearly half of the group concerned South Carolina's Department of Health and Environmental Control (DHEC) and the agency's role in stormwater management. Several respondents felt that they are in a constant battle with DHEC, feeling that the agency offers little oversight to the management process, such that the agency will tell officials what DHEC wants, but will not offer solutions on how to get there. The group felt that DHEC was too focused on select items, such as Total Maximum Daily Loads (TMDLs), and instead should provide a broader perspective on best practices in stormwater management. Before the full report from which this paper was developed, was released, appropriate DHEC officials were contacted for their review and feedback (Allen, et. al.., 2016). Their focus was largely on the earlier discussion related to policy and regulation.

In contrast, several respondents did agree that even with DHEC concerns, the agency is not overbearing at the county level of stormwater management and further finds that DHEC's vague language offers room for flexibility which local officials have benefited from.

Several people noted that they perceive some coastal counties are much more stringent with stormwater standards and regulations compared to the rest of the state. Respondents also noted that stormwater officials remain unsure of what constitutes a "failed" stormwater pond because pond(s) which are non-compliant have not been studied long enough to analyze whether the pond(s) may transform into a productive wetland habitat.

Lastly, focus group participants were open to alternatives to stormwater ponds and other stormwater management through implementing pervious pavers and low impact development (LIDs) techniques into their stormwater management plans. However, participants discussed that LIDs require more maintenance than ponds once installed, are not necessarily cheaper, and require educating engineers, architects, and developers to inform and popularize the idea of implementing LIDs versus the standard pond for stormwater management. Regardless of the concerns with LIDs, focus group respondents clearly believed in the importance of encouraging and supporting LID use as a valuable, alternative tool for community stormwater management and one that would yield important environmental benefits.

One of the final set of comments focused on stormwater managers extending the life cycle of ponds by adjusting current pond development techniques to prolong the pond life and avoiding ponds that serve as an attractant for geese and canine fecal matter. Related to this local land use policies must compliment and incorporate stormwater management and policy changes should be made on the local, not state level. It was also noted that ponds should be functional in that they should enable stormwater detention, flood control, and maintain water quality if properly maintained.

Focus group responses can be an important methodological tool to expanding our understanding of a specific set of issues. However, these results should be considered with caution as these responses are comments from a small group of individuals at a specific point in time. These comments cannot be generalized to represent the opinions of larger groups of professionals or individuals, although there were several key themes that have emerged here: 1) concern over enforcement of maintenance requirements for privately owned stormwater management facilities; 2) issues related to communication and the necessary financial resources of private entities, like HOAs, to be able to adequately manage stormwater facilities; 3) ensuring good communication between MS4 permittees and DHEC and more clarity on how to address impaired waterbodies with TMDLs; 4) better information on whether state or local design requirements for ponds are adequate or effective; and 5) whether LIDs should be a preferred management strategy or at least encouraged. Overall, the goal of this focus group was to add additional depth to our understanding of coastal South Carolina stormwater management policy issues. The focus group accomplished this and brought additional clarity to the research and survey results discussed earlier in this research.

\section{CONCLUSIONS}

The information from the study described above confirms that like many environmental issues today, stormwater pond management lies within a network of layers of regulatory and policy oversight. United States environmental policy, including stormwater, mimics the federalist system in general; with federal and state policies that set standards, have regulatory power and may provide some funding streams, while local municipalities are often left to interpret, implement and/or innovate within this larger policy context. This study was designed and implemented to identify the dominant, overlapping and even conflicting policies or regulations that impact stormwater pond management in the eight coastal counties of South Carolina.

The research presented here provided a brief overview of the federal, state and local policy and regulations related to stormwater pond management and regulation. As with many environmental policy areas, there are several key or landmark policies. For stormwater policy at the federal level, the 1972 Clean Water Act (CWA) amendments and its constituent National Pollutant Discharge Elimination System (NPDES) is the critical federal regulatory policy related to stormwater 
ponds. At the state level, the SC Pollution Control Act and the SC Coastal Management Program provide the SC Department of Health and Environmental Control with stormwater pond regulatory authority and oversight. Counties and municipalities use their comprehensive plans and numerous ordinances for local control and management of stormwater ponds to varying degrees of success and usefulness.

Understanding the flexibility of the policy environment is important in considering opportunities for policy change in the future. As highlighted in this study's survey, focus group, and other data gathering, coastal communities are presented with numerous challenges for ongoing management and enforcement of stormwater pond policy issues. To ensure that these coastal communities remain attractive, beautiful and environmentally healthy places in the future requires a clear picture of the policy and regulatory environment of stormwater pond management today and recommendations for what it should look like in the future. This document helps lay the foundation for future stormwater pond policy studies that can assist policy makers, managers, stakeholders and other decision makers to more fully understand issues impacting water resource management in South Carolina.

\section{ACKNOWLEDGMENTS}

The authors wish to thank the South Carolina Sea Grant Consortium for providing funding for this work. Special thanks go to Dr. Wesley Burnett, Dr. Christopher Mothorpe and Ms. Rachel Hyland of the College of Charleston for their collaboration and assistance with the survey and focus group.

\section{LITERATURE CITED}

Allen, J., L.A. Dickes, K. Buckley, M. Jalowiecka 2016. "Policy Chapter" in the S.C. Stormwater Ponds Research and Management Collaborative State-ofKnowledge Review and Synthesis. South Carolina Sea Grant, http://www.scseagrant.org/.

Beaufort County, South Carolina. 2015. "Stormwater Management Department." Online. Retrieved 15 Oct 15 from http://www.bcgov.net/departments/Engineering-andInfrastructure/stormwater-management//index.php

Berkeley County Government. 2015. "Stormwater Management Program.” Online. Retrieved 28 Oct 15 from https://www.berkeleycountysc.gov/drupal/ engineering/storm

Charleston County Government. 2015. "Stormwater Management Program.” Online. Retrieved 21 Oct 15 from http:/www.charlestoncounty.org/departments/ public-works/stormwater.php

City of Beaufort, South Carolina. 2015. "City of Beaufort Government.” Online. Retrieved 4 Nov 15 from http:// www.cityofbeaufort.org/
City of Charleston, South Carolina. 2015. "Stormwater." Online. Retrieved 4 Nov 15 from http://sc-charleston. civicplus.com/index.aspx?NID=350

City of Myrtle Beach, South Carolina. 2010. "Welcome to Myrtle Beach." Online. Retrieved 30 Oct 15 from http:// www.cityofmyrtlebeach.com/

Colleton County, South Carolina. 2013. "Documents." Online. Retrieved 18 Oct 15 from http://www. colletoncounty.org/documents

Committee on Reducing Stormwater Discharge Contributions to Water Pollution, Water Science and Technology Board, and National Research Council. 2008, October 15. "Urban stormwater management in the United States.” Online. Retrieved 25 June 15 from http://water.epa.gov/polwaste/npdes/ stormwater/upload/ nrc_stormwaterreport.pdf

Davis, A., B. Pijanowski, K. Robinson, and P. Kidwell. 2010. Estimating parking lot footprints in the Upper Great Lakes Region of the USA. Landscape and Urban Planning 96: 68-77.

Dorchester County. 2015. "Stormwater Management." Online. Retrieved 23 Oct 15 from http://www. dorchestercounty.net/index.aspx?page $=90$

Ellis, K., C. Berg, D. Caraco, S. Drescher, G. Hoffmann, B. Keppler, M. LaRocco, and A.Turner. 2014. "Low Impact Development in Coastal South Carolina: A Planning and Design Guide." Online. Retrieved 18 June 15 from http:// www.northinlet.sc.edu/lid/FinalDocument/loRes/LID\%20 in\%20Coastal\%20SC_low\%20res.pdf

Gaba, Jeffrey,M. 2007. “Generally Illegal: NPDES General Permits Under the Clean Water Act." 31 HARV. ENVTL. L. REV. 409: 469-471.

Georgetown County. 2015. "Welcome to Georgetown County Stormwater." Online. Retrieved 19 Oct 15 from http://www.georgetowncountycleanwater.com/

Georgetown, South Carolina. 2014. "Storm Drainage." Online. Retrieved 6 Nov 15 from http:// cityofgeorgetownsc.com/water-utilities-department/ storm-drainage/

Horry County Stormwater Management. 2014. "Horry County Stormwater Management." Online. Retrieved 17 Oct 15 from http://stormwater.horrycounty.org/

Jasper County Government. 2015. "Zoning and Land Development Regulations." Online. Retrieved 20 Oct 15 from http://www.jaspercountysc.org/secondary. aspx?pageID $=248$

Powell, B. A. 2009. "Stormwater Ponds- Purposes and services of stormwater ponds." Online. Retrieved 10 Nov. 14 from http://www.clemson.edu/public/carolinaclear/ cc toolbox/pubs_pdfs/2011/pondseries_bpowell_010209.pdf.

Richard Geer, e-mail message to DHEC employee, August 25, 2015. 
SafeDrain. 2010. "Stormwater BMP." Online. Retrieved 09 Nov. 14 from http://spillsafe.com/stormwater-bmp.

South Carolina Code of Laws. Title 6, Local Government Provisions Applicable to Special Purpose Districts and Other Political Subdivisions. Online. Retrieved December 12 from http://www.scstatehouse.gov/code/t06c029.php.

South Carolina Department of Health and Environmental Control. 2014(A). "Coastal Zone." Online. Retrieved 17 July 15 from http://www.scdhec.gov/Agency/ RegulationsAnd Updates/Laws AndRegulations/Coastal/ South Carolina Department of Health and Environmental Control. 2014(B). "Stormwater Permitting: Overview." Online. Retrieved 16 July 15 from https://www.scdhec. gov /Environment/WaterQuality/Stormwater/Overview/ South Carolina Department of Health and Environmental Control. 2010, March 29. "Fact Sheet: Industrial Storm Water (Except Construction) General NPDES Permit; SCR000000.” Online. Retrieved 28 July 15 from http:// www.scdhec.gov/Environment/docs/sw_PNFSIGP.pdf

South Carolina Department of Health and Environmental Control Office of Ocean and Coastal Resource Management (SCDHEC-OCRM). 2011, January. "South Carolina Coastal Zone Management Program Section 309 Assessment and Strategy 2011-2015." Online. Retrieved 23 July 15 from https://coast.noaa.gov/czm/enhancement/ media/ sc3092011.pdf

South Carolina Department of Health and Environmental Control Office of Ocean and Coastal Resource Management, South Carolina Sea Grant Consortium, Drescher, S.R., M. Messersmith, B. Davis, and D. Sanger. 2007, October. "State of the Knowledge Report: Stormwater Ponds in the Coastal Zone. Retrieved 8 July 15 from http://www.scdhec.gov/HomeAnd Environment / Docs/SOK_Ponds.pdf

South Carolina Legislature. 2014. "South Carolina Code of Laws Unannotated Current through the End of the 2014 Session.” Online. Retrieved 20 July 15 from http://www. scstatehouse.gov/code/ t48c039.php

Town of Mt. Pleasant Municipal Complex. n.d. "Stormwater." Online. Retrieved 1 Nov 15 from https:// www.tompsc.com/index.aspx?nid=197

United Nations Environmental Programme. n.d. "IEA Training Manual - Module 5 - 6.5 Step C: The policy instrument scan." Online. Retrieved 15 December 16 from: http://www.unep.org/ieacp/iea/training/manual/ module5/1235.aspx.

U.S. Environmental Protection Agency. 2015, August 28. "The Final Clean Water Rule." Online. Retrieved 1 Nov 15 from http://www2.epa.gov/cleanwaterrule/finalclean-water-rule

U.S. Environmental Protection Agency. 2011. "Water" Online. Retrieved 12 Nov. 14 from http://water.epa.gov/.
U.S. Fish and Wildlife Service. 2015, May 20. "Endangered Species.” Online. Retrieved 23 June 15 from http://www. fws.gov/endangered

U.S. National Park Service. n.d. "Gullah/Geechee Cultural Heritage Corridor: North Carolina, South Carolina, Georgia, Florida." Online. Retrieved 23 June 15 from http://www.nps.gov/nr/Travel/cultural_diversity/Gullah_ Geechee_Cultura 1_Heritage_Corridor.html

U.S. National Research Council (USNRC). 2008. "Urban Stormwater Management in the United States." Online. Retrieved 15 December 16 from https:// www3.epa.gov/npdes/pubs/nrc_stormwaterreport.pdf.

Vandiver, L and D. Hernandez. 2009. Assessment of Stormwater Management in Coastal South Carolina: A Focus on Stormwater Ponds and Low Impact Development (LID) Practices. http://www.scseagrant.org/ pdf_files/stormwater_assessment_report_web.pdf

White, M. and K. Greer. 2006. The effects of watershed urbanization on the streamhydrology and riparian vegetation of Los Penasquitos Creek, California. Landscape and Urban Planning 74: 125-138. 